\title{
The Practical Way of Communist Party of China to Bring up and Assemble Young Talents in the Early Years of Reform and Opening up (1978-1989)*
}

\author{
Wu Xia, Luo Hongtie \\ Southwest University, Chongqing, China
}

\begin{abstract}
In 1978, China entered the era of reform and opening up. Faced the great depression, cultivating and assembling young talent became an important power to support rapid development of the country. The leadership of Communist Party led by Deng Xiaoping had a global sight, and began to reform higher education system, gradually cultivated and assembled the generation of young talents. This paper reviews the theoretical ideas and practical measures of Communist Party of China (CPC) to train and assemble young talents at the beginning of reform and opening up, analyzes and displays the particular and scientific method of young talents and the great achievements of young talents in this period. The paper consists of three parts, the practice of bringing up young talents, young cadres, young professional and technical personnel, and the modernization construction from young talents. These methods cultivate so many young talents as the pillars of state development, and the quality of youth increased rapidly. So many practical ways also have been used and influenced in China today, and these are not only the wealth for China, but also the important experience for the whole world.
\end{abstract}

Keywords: young talent, practical way, bring up and assemble, reform and opening up, Communist Party of China (CPC)

On December 18-22, 1978, the Third Plenary Session of the 11th Central Committee of the Communist Party of China (CPC) was held in Beijing. Plenary highly praised the discussion about "Practice is the sole criterion for testing truth" and decided to stop the use of slogan about "taking class struggle as the most important key", "continuing the revolution under the guidance of the proletariat", made strategic decision of "transferring the whole importance of party and the whole focus of people to the socialist modernization". This committee served as a great turning point, and became a milestone of the start of China's reform. In this context, the deficiency of young talents had become the key issues and the CPC paid attention to education and assembling young talent.

\footnotetext{
* The paper is supported by "the National Social Science Funds" (2011 \& ZD069), "the Fundamental Research Funds for the Central Universities" (SWU1409304), and "Humanities and Social Science Research Funds in Education Commission of Chongqing" (14SKZ06).

Corresponding author: $\mathrm{Wu}$ Xia, Ph.D., lecturer, Institute of Marxism, Southwest University, China; research fields: ideological and political education, psychological education, and talent education. E-mail: wuxia1982@hotmail.com.

Luo Hongtie, professor, doctoral tutor, Institute of Marxism, Southwest University, China; special allowance by the State Council, academic committee member in the National Research Council of Ideological and Political Education, executive vice president in China Talent Research Society; research fields: ideological and political education, talent education. E-mail: lht@swu.edu.cn.
} 


\section{In the Early Year of Reform and Opening up the Practice of Bringing up Young Talent}

To bring up young talent dedicated to the modernization, the CPC in this period explored practical ways on the training of young talents.

\section{The CPC Reformed Higher Education System to Speed up the Growth of Students}

Deng Xiaoping came back at the third time and volunteered in charge of science, technology, and education. He was the first one who sensed the problem of ideas and concepts of education and clarified the meaning and role of proper evaluation of the education for the establishment of nation of 17 years. So, he personally led and carried out the order restoration of higher education, recovering the idea of higher education as the basis of teaching talent, which set right track of talent training. On August 8, 1977, Deng Xiaoping presided over seminar about the science and education. In this seminar, he said,

Before most of the time of the Culture Revolution, the basic spirit of a series of instructions of Mao Zedong for scientific research, cultural and education are to encourage and to promote. It is estimated that the majority of our intellectuals like socialism or is willing to adapt socialism. (Deng, 1994, p. 48)

"How to estimate the value of National Education for 17 years? In my view, dominant aspect of work in the red line should be affirmed" (Deng, 1994, p. 49). After restoration of order in higher education, intellectuals had right to set their talent. Among research about the examination system and exploration of teaching content, among the prevention of too heavy burden of students and improving the standard of students' science and culture, the quality of higher education had been developed in all "moral, intellectual, physical" areas. At the end of 1979, the country supported 97 colleges and universities (Xia, 2004), making efforts to train talents in professional subjects, and laid a solid foundation for the great development of education. Meanwhile, CPC reopened college entrance examination to promote the great development of higher education. In 1977, Deng Xiaoping convened more than 40 scientists to take a meeting concerning the problem of the reopening of the college entrance examination. At this meeting, Deng made a prompt decision and said,

This year, we must be determined to resume the college entrance examination which directly face to graduates from high school, not engage in admissions from the masses recommended. I think, direct administration in graduates from high school probably will be a good way to preselect talents. (Literature Research Center of Communist Party, 2004)

In December 1977, closing a decade of college entrance examination re-ushered candidates, and reopened a door of hope for studying in universities. In that year, it had been enrolled college freshmen of 27.3 million, accounting for $4.7 \%$ among $5,700,000$ candidates. Six months later in 1978, total participants of summer college entrance examination were 61.5 million and among them about 402,000 freshmen were admitted (Zhang, 2007). Reopening the college entrance examination and promoting the development of higher education were of a great importance for selecting and training young talents. In addition, restoration and development of the graduate degree education fundamentally promoted the development of China's higher education, and promoted the rapid growth in the number of high-level talents. From 1978 to 1985, the number of students in colleges and universities rose from 62 million to 170 million, more than doubled. The growth of the number of graduated students was more obvious. Two hundred and ten universities and 162 research institutes were involved in postgraduate training. In 1978, the country planned to enroll 8,986 students, and the actual enrollment number was 10,708 , which was three times larger than the most number of admissions before 
the Cultural Revolution (Zhang, 2011). Restoration and development of graduate education gave young people a good opportunity to upgrade their talents and a new stage to possess higher wisdom in life. Meanwhile, the restoration of sending students for overseas study became an important way to improve the level of young talents. On June 23, 1978, when discussed with the President of Tsinghua University Deng Xiaoping said:

I am in favor of increasing the number of students studying abroad, who are mainly engaged in the natural science. The management of students studying abroad should be established closely, but not in an inflexible way. If it is afraid of contact with the society, that's not beneficial to learn a foreign language and know more about the society. So we should together with others to establish an order to learn more. This is an important way to improve the level rapidly in five years. We want to send more and more students to study abroad, not only a few. Ministry of Education should look into how much money to spend, it is worth. We want to send a group of graduates from high school go to college abroad who have good foundation in foreign language. This year could send three or four thousands, next year ten thousands, which is a good way to accelerate the speed. $(\mathrm{Li}, 2000)$

Deng Xiaoping's views about the overseas study were at the strategic level of the country's four modernizations. The number of talents by studying abroad at public expanded year by year. From 860 talents in 1978 to 14.45 million in 2007, the number of studying abroad expanded 168 times in 30 years. The destination countries were also all over the world. From 1978 to the end of 2007, the number of various studying abroad was totally 121.17 million in more than 100 countries (Pan \& Jia, 2008). Because of the restoration of sending students abroad, the reform, and innovation initiatives, there has been an unprecedented large-scale young talents studying abroad in the history of China. It not only filled the shortage and faults of talents, but also reinforced the quality of research and teaching teams. That became an important method for the country to improve the level of education.

\section{The CPC Developed Rapidly in Adult Education}

In the same period, China wanted to find out "what is about socialism and how to build socialism", and developed the productive forces. In order to meet the needs of economic reform and social development, CPC also speeded up the reform and development of adult education. In February 1981, the CPC and State Council promulgated "the Decision on Strengthening the Work of Staff Education" ([1981] No. 8), which was a sign to highlight the adult education. In December 1986, the First National Adult Education Conference had been held. After this conference, State Council batched file transfer State Board of Education "the Decision on Reform and Development of Adult Education" in June 1987, which established the status of the adult education. "Adult education is the necessity for the development of the modern society and advances of science and technology". "Adult education is an important part of education in China". And that developed the training direction of adult education. "Adult education mainly concerns the employees who have embarked on a variety of jobs. And successful adult education can directly and effectively improve the quality of workers and staffs for better economic efficiency and productivity". The rapid development of adult education enriched the network system of training young talents, and built a new bridge of education for all the young people in rural area and illiteracy.

\section{The CPC Increased the Basic Education to Cultivate the Reserve of Young Talents}

Firstly, the CPC implemented a variety of textbook development emphasizing the unified basic requirements. Textbook is the foundation and core of education. But affected by the Cultural Revolution, there was lack of high school textbooks, with unified contents and outline. Given the need for such a massive work, the Ministry of Education worked to organize experts to write primary and secondary school for all students, 
and proceeded to develop a new outline in September 1977. In the middle of 1980s, the work was also focused on solving the problem of lack of diversity and flexibility of unified textbook in a new round of reform. This reform put forward the textbook which met the learning and training needs of various levels of student and was suitable for the actual teaching of various regions.

Secondly, the CPC implemented "the Law of Compulsory Education in People's Republic of China (Draft)" which established the security system of basic education. "The Law of Compulsory Education in People's Republic of China (Draft)" had been approved by the Fourth Meeting of the Sixth National People's Congress and came into effect on July 1, 1986. According to the National Bureau of Statistics, the enrollment of school-age children in 1985 was $96 \%$ and increased $1.2 \%$ in 1988. And the number of primary school teachers also increased from the 537.7 million to 550.1 million.

Finally, the CPC actively promoted the "Universal Primary Education" and the "Compulsory Education in nine years". On December 3, 1980, the CPC and State Council enacted the "Decision on Several Issues of Universal Primary Education", and proposed five demands to promote the beginning of the "Universal Primary Education" and the "Compulsory Education in Nine Years" which played a clear and important role of education in the building of "Four Modernizations". On May 27, 1985, CPC published the "Decision on Education Reform" which pointed out the improper administrative privileges of the division of educational affairs in education system, the educational structure, educational thought, educational content, and educational methods. National government devolved the authority of implementation of "Compulsory Education in nine years" to regions. The "Universal Primary Education" and the "Compulsory Education in Nine Years" realized the dream of study for generations.

\section{In the Early Year of Reform and Opening up the Practice of Bringing up Young Cadres}

At the beginning of reform and opening up, the problem of lacking young cadres was severe. In order to solve this problem, the CPC began to recover Party School and Youth League, which mainly trained cadres. Then the system of training young cadres, training methods, selection and appointment of young cadres were reformed. The CPC persisted in emancipating the mind, overcoming obstacles, and breaking old traditions. Party School and Youth League trained and gathered a group of outstanding young talent of cadres.

\section{The CPC Recovered Party School and Youth League to Ensure Regularization of Training Young Cadres}

In 1977, the Department of Propaganda and the Department of Organization issued "the Opinions on Strengthening the Work of Cadre Education", which contained "with the focus of the party's work to socialist modernization, the imperative of re-education of cadres". Thus, the recovery of education in Party School and Youth League started under the guidance of the CPC. In October 1977, the CPC published "the decision to run all levels of Party School" which proposed the direction and requirements for the recovery of education, and explicitly clarified the position and role of the Party School in defending Marxism-Leninism and Mao Zedong Thought. In May 1978, the CPC issued a notice to the 10th Congress of the Youth League: "We should strive to do the training of young cadres of Youth League, and immediately recover the various administrative levels of Central Youth League", which set up the Central Youth League and the Youth League in every provinces, municipalities, and autonomous regions. Recovery of the Party School and Youth League gave a group of 
young cadres to learn the theory of Marxism. From short-rotation to academic education, the educational system of Party School was normalization, standardization, and institutionalization. Young cadres learned political thoughts, theoretical knowledge, and operational capacity in the use of Marxist-Leninist ideology to practice work on their way to leadership position. The training of Party School and Youth League fostered a group of young cadres with strong ideological quality and solid operational capacity in the reform and opening up period.

\section{The League Did the Ideological and Political Education Relying on the Activity of "Four Points of Beauty"}

The activity of "Four Points of Beauty" aims to propagate the rich content of socialist spiritual civilization in "civilized, polite, hygiene, as well as order, ethical" and "spiritual beauty, the beauty of language, behavior, and environment", which served as a strong starting point in Party's ideological and political education. On February 15, 1981, the Central of Youth League jointed other nine departments to make a decision about "the Initiative on Carrying out Activities in Civility", emphasizing the culture of "Four Points of Beauty" in young cadres. Young cadres set up a "youth service team" in the spirit to serve people heart and soul inherited from Lei Feng. They started the activity of "helping young and giving warm" in millions of young, social organization to care and help backward youth. These activities improved the level of understanding, appreciation, and pursuit in young cadres. As the result of these practice of ideological and political education in young, the love of motherland, socialism, and Communist Party, as long as the pursuit of communist beliefs was rooted in the hearts of young.

\section{The CPC Reformed the Personnel System to Promote the Organizational Security of Young Cadres Training}

Firstly, the training and selection of young cadres was elevated to the strategic level. In November 1979, Deng Xiaoping pointed out, "we must recognize that the training and selection of young cadres is a strategic issue, which is related to the long-term benefits of the party and the country" (Deng, 1994, p. 222). To this end, the party had undertaken new measures in four areas. The party implemented the principle of collective succession, which realized health natural leadership transition and re-established the employment outlook emphasizing the value of party, the performance, and the public opinions. The Communist Party got rid of old ideas of seniority and demanding perfection. The party also seized the reserve cadres (Fu, 2010). Thus, the direction and goals of training young cadres were clearly manifested. And more young cadres had better opportunities to access to education for improved self-quality.

Secondly, the CPC explored the abolition of life tenure in leading posts. In February 1980, the party firstly proposed clearly that it would abolish life-long tenure of leading cadres in the Fifth Plenary Session of the Eleventh. Later, in the speech of "Reform Leadership System in Party and State" from Deng Xiaoping, he proposed the abolition of life tenure in leading posts was the need for the conditions of China and the socialist modernization, which promoted the reform of the personnel system profoundly. In 1982, the party published the "Decision on Establishment of the Veteran Retirement System" which made specific provisions about the details of this system, for example, the age of the retirees. A number of veterans with limited energy retired or took a back seat. At the same time, the party boldly selected young cadres to refine and display their talents on the main leadership positions at all levels. Replacing the old cadres had been completed stably and smoothly. The transfer of power provided a more effective organizational guarantee for the training of young cadres, and 
gradually shaped young cadres to become "more revolutionary, younger, better educated and professional with solving practical problems".

\section{The Experience of Work in Grass Roots Promoted the Growth of Young Cadres}

Working in grass roots became one of the effective ways of young cadres training, which tempered working capacity and sharpened willpower of young cadres. In September 1983, the Organization Department issued "the notice for sending a part of young cadres in the state organizations to exercise in the grass roots". To cultivate the talent of young cadres, improve the quality of them, and promote the construction of the third echelon talent, a group of young cadres with tertiary education worked in the grass roots and gained considerable progress and development. Life of the grassroots became a life platform of training young cadres, and the basic level work became a whetstone to increase their abilities. "The prime minister is always developed from the gun, and the army general is always developed from the soldier". There were so many changes in the situation of grassroots working and various persons contacted. Because of this situation, it was urgent to improve the service qualities and the working capacities of young cadres to solve complex problems and emergencies.

\section{In the Early Year of Reform and Opening up the Practice of Bringing up Young Professional and Technical Personnel}

At the beginning of reform and opening up, the party was very concerned about the talent of young professional and technical personnel, and took various measures to train them. It created the training atmosphere about advocating science and technology.

\section{The Postdoctoral System Helped to Training the Young Senior Professionals}

In 1985, the State Council approved the "Report of Pilot Post-doctoral Research Station from Ministry of Science and Technology, Ministry of Education and Chinese Academy of Science". The country enacted this national policy to establish the postdoctoral system. From 1981 only one post doctor as a starting point, the scale of recruiting postdoctoral had been increasing every year. In 1986, it recruited 68 postdoctoral, and 100 in 1987. In 1986 and 1987, it also increased two and five post-doctoral research stations, and every station was preparing for training young senior professionals. The postdoctoral system gradually became mature, and the training of young senior professionals also were gradually prosperous, which delivered more and more high-quality personnel with innovative and development ability for the socialist modernization. The postdoctoral system not only improved the capacity of research, but also improved the capability of independent innovation. According to statistics, every postdoctoral researcher at the station undertook 2-3 important research projects on average, $40 \%$ of which were national projects and the rate of project completion was $64 \%$ in two years. Every postdoctoral researcher published 1.5 papers in international journals and 3.4 papers in domestic core journals on average. They won 0.5 awards at provincial level or above. And $19.2 \%$ of post-doctoral researchers got technology achievement award or honor at ministerial level or above (Zhou, 2001).

\section{The CPC Set National Awards and National Projects to Promote the Development of Young Professional and Technical Personnel}

In 1986, the State Council began to set up the Committee of National Natural Science Foundation which opened channels of National Natural Science Fund. The aim of setting up the fund was to support basic 
research and some applied research, the discovery and training personnel, promoting scientific and technological progress and economic and social development in guiding and coordinating way (State Council on the Establishment of National Natural Science Fund Committee). Among this fund, there was a "Youth Science Fund" project for young researchers, which unequivocally supported the training of young personnel. The fund not only became an important training channel for the high-level scientific and technological personnel, but also became an important mode to assemble young personnel including those in the management of fund. At the same year, the State Council approved another project to promote the development of Science and Technology_ "863" Project. This project focused on the principle of "limited objectives, prominent focus". It chose seven areas such as biotechnology, and space technology, and 15 topics as the priorities of national high-tech research and development. And the State Council allocated 10 billion yuan to support "863" Project. At the stage of "Seventh Five-Year Plan", "Eighth Five-Year Plan", and "Ninth Five-Year Plan", the number of young scientists who participated the "863" Project reached 30,000. A series of achievements with sophisticated features had been burst out. According to statistics, by the end of 2008, the percentage of young experts below 45 years old who worked in the Committee of " 863 " Project had been more than $30 \%$. And it had trained 10,000 doctors, masters and other senior young scientists in 15 years (Wei $\&$ Tian, 2008).

\section{The Enterprise Attracted and Trained Young Talents}

It was a shortcut for exploring development of enterprises by the way of training young talents. "Training of talents, not just is not limited to a few of engineers, technicians, it should create a large number of young talents with ideas, technology, and achievement in their own posts" (People's Daily, 1986). From May 1985, the Shanghai No. 3 steel factory which had more than 9,000 young workers carried out "Striving to talents" activity, which guided young workers to establish the correct concept of talents. Many young workers who came from rural areas and had poor technical skills got training in production practices. They not only delivered the achievements with technological innovation, but also became talents with more comprehensive technology literacy. The Baosteel in Shanghai also trained young talents in the method of "emphasizing planning, the source, attention to education, emphasizing rotation, training, assessment, incentives, investment and system" (Guan, 1995). It made a plan to establish the reserve team of 300 young entrepreneurs, and spent 500 million every year to train reserve young cadres. Also it developed the "Trail System of Exchange Cadre in Baosteel" which formed a complete system of talents training strategy.

\section{The CPC Guided Young Talents to Actively Participate in Modernization Construction}

The development of the country had gratifying achievements with pride in the decades of reform and opening up. The party was committed to assemble the young talents, and guided them participate in the socialist modernization construction. The young talents made their contribution of intelligence to the development of the country.

Firstly, the CPC guided young talents participate in the construction of socialist democratic politics. Young talents were encouraged to actively join the CPC and participate in the reform of party and the country. Two hundred million young cadres in 1980s became the most active force in the construction of the country. Secondly, the party guided young talents to participate actively in economic construction. Young talents played 
an active role in the construction of the industrial economy, and promoted the development of social productive forces. They rushed to carry out the activity about "contribution of youth to focus on building, striving to be experts in the new Long March". Job training, technical competition, and demonstration of civilized business greatly stimulate the working enthusiasm of young talents in public transport, infrastructure, finance and trade, and other industrial economy. Young talent also worked hard in the agricultural economic development, and promoted the development of agriculture in economic construction. In the middle of 1980s, labor rich created an upsurge among rural youth which were effectively coordinated with the reform of the rural economy and promoted the development of agricultural production. Thirdly, the party guided young talents to participate in scientific research. Young talents showed their wisdom on academic forums. In the summer of 1986, Shanghai Branch of Chinese Academy of Sciences organized the "Biological Sciences Symposium for Youth". The symposium with 115 young scientists received 174 papers. The young talents presented so much academic reports, made poster exchanges, and discussed academic frontier issues with renowned scientists. Then young talents made their contribution to various research areas such as in mathematics, proposed the theory of compensated compactness, in physics, the study of gas dynamics equations, as well as five and eight symmetric quasicrystals, in biology and chemistry, yeast alanine transfer RNA (Ribonucleic Acid) synthetic, structural analysis and synthesis of artemisinin. Fourthly, the party guided young talents become the new force in education, culture, health, and sports areas. Young talents worked hard in the education system. In the period from 1980 to 1987, the number increased from 63 million to 97 million for university teachers, from 30 to 46 million for college teachers, and from 605 million to 608 million for the number of primary school teachers. Most of them were nearly 35-year-old young teachers (National Bureau of Statistics Yearbook). Young talents just had success in the culture area. Some books of young writers, for example, "Note for the Factory Director Joe" written by Jiang Zilong and "Three Million" written by Ke Yunlu, and so on. They aroused strong repercussions in the community as soon as they published. And so many plays from young directors and players became the spiritual food for the masses, for example, "Legend of Tianyun Mountain", "Middle-Aged", "Hibiscus Town", and so on. "Red Sorghum" which was directed by young talent Zhang Yimou even got the highest award of international-Golden Bear in the Berlin Film Festival. Also Chinese young athletes gained many honors in international competitions. From July 28 to August 12 in 1984, Chinese team first appeared in the Summer Olympic Games after the recovery of International Olympic Committee seats. Most young athletes were under the age of 35 in the whole 225 Chinese athletes. Many of them were the outstanding representatives of young athletes, for example, Xu Haifeng, Li Ning, the Chinese women's volleyball team, Zhou Jihong, Luan Jujie, and so on.

At the beginning of reform and opening up, the CPC made breakthrough in understanding of the importance of training young talents, and interpreting the meaning and role of education with scientific dialectical methods. Then it implemented the awareness of training young talents into practice, and found a way to train and assemble young talents which suited for the national development. As playing piano with ten fingers, young talents in each area should be trained and assembled. This practical way to bring up and assemble young talents spread all over areas of science, politics, and culture, etc. So China was extremely active and vital after the trauma of the Cultural Revolution, and young talents got an unprecedented development opportunity. It became a typical experience of using Marxism thoughts to bring up and assemble young talents. 


\section{References}

Deng, X. P. (1994). Works of Deng Xiaoping (Vol. 2). Beijing: People's Publishing House.

Fu, Z. Y. (2010). The process and experience of the reform of the cadre system since the reform and opening up. JAC Forum, 3, 77-79.

Guan, Z. M. (1995). Baosteel training of talents practices. Metallurgical Management, 9, 17-20.

Li, T. (2000). History of abroad studying in China-After 1949. Beijing: Higher Education Press.

Literature Research Center of Communist Party. (2004). Deng Xiaoping's theory of education. Beijing: People's Education Press.

Pan, L., \& Jia, J. X. (2008). Vast soar-New brilliant of abroad studying in the 30 years of reform and opening up. Chinese Talent, 21.

People's Daily. (1986, May 4). Growth based on workers' own ability to make contributions to the revitalization of the steel industry. People's Daily, 4th edition.

Wei, X. Y., \& Tian, L. (2008). On the important influence of the high-tech research and development program of university of science and technology. Modern Economic Information, 7, 117-118.

Xia, X. Z. (2004). Deng Xiaoping and the order out of chaos in education. Chinese Contemporary History, 11, 50-58.

Zhang, C. (2011). Tradition and transformation of contemporary degree system. PhD thesis, Southwest University.

Zhang, L. T. (2007). Interpretation of the significance of the re-opening college entrance examination. Journal of Nanjing Normal University (Social Science Edition), 6, 74-78.

Zhou, F. (2001). Focus on China postdoctoral. Chinese Civil Servants, 6, 13-14. 